\title{
HANE İÇİ GELİRİN KONTROLÜ VE HARCAMALARIN DAĞILIMI ÜZERİNE BİR ARAŞTIRMA*
}

\author{
Çisel EKİZ GÖKMEN ${ }^{* *}$
}

\section{Özet}

Hane davranışını inceleyen uluslararası çalışmalar, hane içinde geliri kimin kontrol ettiğinin harcamaların hane üyeleri arasındaki dağılımın etkilediğini ortaya koymaktadır. Türkiye gibi ataerkil yapının baskın olduğu ülkelerde ise gelirin kontrolü genellikle erkeğin elinde toplanmaktadır. Bu çalışma Mardin ve Muğla örneğinden hareketle Türkiye'de hane üyeleri tarafindan elde edilen gelirin birleştirilip birleştirilmediğini araştırmayı ve gelirin kontrolünün kadınların veya erkeklerin elinde olmasının harcamaların hane içi dağılımı üzerindeki olası etkilerini incelemeyi amaçlamaktadır. Bu amaçla 2010-2011 yılları arasında, farklı sosyo-ekonomik özelliklere sahip 408 evli çifte anket uygulanmıştır. Alan araştırması sonuçları gelirin kontrolünün kadınların elinde olmasının çocuklara yönelik harcamaları arttırdığın göstermekte, bu anlamda uluslararası literatür bulgularını desteklemektedir.

Anahtar Kelimeler: Bireysel Gelir, Pazarlık Gücü, Hane İçi Harcamalar, Muğla, Mardin.

JEL Sınıflaması: D13, D31.

\section{A RESEARCH ON INTRA HOUSEHOLD CONTROL OF INCOME AND DISTRIBUTION OF EXPENDITURE}

\begin{abstract}
International studies examining the households behavior reveals that the distribution of expenditures within the household is affected by who controls the income. Income is generally controlled by men in the countries such as Turkey, which are predominantly patriarchal structure. This study aims to analyze if personal income owned by household members was pooled or not and also examine the possible impact of income controlled by women or men on intra-household distribution of expenditure in Turkey in the central district of Mardin and Muğla. For this purpose, a questionnaire was conducted to 408 married couples that have different socio-economic backgrounds. Field research results show that the income control by women increases spending for children and supports the findings of the international literature in this regard.
\end{abstract}

Keywords: Personal Income, Bargaining Power, Intra-Household Expenditure, Muğla, Mardin. JEL Classification: D13, D31.

* Bu çalışma TÜBİTAK’ın Bilimsel ve Teknolojik Araştırma Projelerini Destekleme Programı (1001) tarafından desteklenmiștir (TÜBİTAK Proje No: 110K193).

** Yrd. Doç. Dr., Muğla Sttkı Koçman Üniversitesi, İktisadi ve İdari Bilimler Fakültesi, Çalışma Ekonomisi ve Endüstri İlişkileri Bölümü, eposta: cekiz@mu.edu.tr. 


\section{Giriş}

Hane üyeleri arasında kararların nasıl alındığına, gelirin ve harcamaların hane içinde nasıl dağıldığına ilişkin hanehalkı davranışlarını açıklayan üniter ve kolektif model olmak üzere iki temel model bulunmaktadır. Üniter modeller hanehalkının hane içi kararlarda her zaman hemfikir olan bir bireymiş gibi davranarak gelirlerini birleştirdiğini ve haneye kim tarafından ne kadar gelir getirildiğinin harcamaların hane içerisindeki dağılımını etkilemediğini varsaymaktadır ${ }^{1}$. Ancak son yıllarda gerek gelişmiş gerek gelişmekte olan ülkeler için yapılan çalışmalar üniter hanehalkı modelinin hane üyelerinin öncelik ve tercihlerde her zaman hemfikir olduklarına ve hane üyelerinin gelirlerini birleştirdiklerine ilişkin temel varsayımlarının her zaman geçerli olmadığını ortaya koymuştur ${ }^{2}$. Gelir birleştirme hipotezinin reddedilmesi ise haneye getirilen gelirin birleştirilmediği ve hane üyeleri tarafından hane ekonomisine parasal katkı yapılıp yapılmamasının ve eğer yapıldıysa miktarının harcamaların hane içerisindeki dağılımını değiştirdiği anlamına gelmektedir. Kısaca hane içerisinde gelir elde etsin veya etmesin harcamaları hane üyeleri arasında eşit bir şekilde dağıtan "görünmez bir el" bulunmamaktadır.

Üniter modelin varsayımlarının zayıflatılması üzerine genel olarak hanedeki bireylerin gelirlerini birleştirmediğini ve farklı hane üyelerinin farklı tercihlere, farklı "pazarlık güçlerine" ve söz konusu unsurların etkileşiminin bir sonucu olarak hanehalkı içinde farklı harcama dağılımı sonuçlarına sahip olduklarını varsayan kolektif modeller öne çıkmıştır ${ }^{3}$. Kolektif hanehalkı modelinde, harcamaların hane içerisindeki dağılımı bir kişinin kaynakları kontrol etmesi veya hane içi pazarlık gücü tarafından belirlenmektedir. Hane içi pazarlık gücünün göstergesi olarak bireysel geliri ele alan uluslararası çalışmalar, sahip olunan gelirin harcamaların hane içerisindeki dağılımını etkilediğini ve toplam hane geliri içerisinde kadınların gelirinin payının az olduğu hanehalkında, kadınların toplam harcamalardan daha az pay aldıklarını ortaya koymuştur ${ }^{4}$. Türkiye gibi ataerkil yapının baskın olduğu ülkelerde ise gelirin kontrolü genellikle erkeklerin elinde toplanmaktadır. Bu ise hiç kişisel geliri olmayan veya düşük gelir düzeyine sahip olan kadınların hane içerisinde neden harcamalardan eşit bir pay al(a)madığının göstergesidir. Yine hanehalkı davranışlarının kolektif modellerini inceleyen uluslararası çalışmaların önemli bir kısmı, gerek gelişmiş gerek gelişmekte olan ülkelerde gelirin kontrolünün kadınların elinde olmasının ve kadınların kontrol ettiği gelirin artmasının, özellikle çocuklara yönelik eğitim, sağlık ve gıda gibi harcamaları arttırarak, harcamaların hanehalkı içerisindeki dağılımını

1 Becker, G. S. (1991). A Treatise on the Family, Enlarged Edition, USA, Harvard University Press. Alderman H. ve diğerleri (1995). Unitary versus Collective Models of the Household: Is It Time to Shift the Burden of Proof?, World Bank Research Observer, 10(1): 1-19.

2 Thomas, D. (1990). Intra-Household Resource Allocation: An Inferential Approach, The Journal of Human Resources, 25(4): 635-664. Thomas, D. (1992). The Distribution of Income and Expenditure within the Household, Annales d' Economie et de Statistique, (29): 109-136. Bourguignon, F. ve diğerleri (1993). Intra Household Allocation of Consumption: A Model and Some Evidence from French Data, Annales d' Economie et de Statistique, (29): 137-156.

3 Manser M., Brown, M. (1980). Marriage and Household Decision-Making: A Bargaining Analysis, International Economic Review, 21(1): 31-44. McElroy, M. B., Horney, M. J. (1981). Nash-Bargained Household Decisions: Toward a Generalization of the Theory of Demand, International Economic Review, 22(2): 333-349.

4 Browning, M. ve diğerleri (1994). Income and Outcomes: A Structural Model of Intrahousehold Allocation, The Journal of Political Economy, 102(6): 1067-1096. 
daha çocuk merkezli bir hale getirdiğini ortaya koymuştur ${ }^{5}$. Ancak Türkiye'de hane içi gelirin kontrolünün harcamaların mevcut dağılımını nasıl etkilediğini ve kadınların veya erkeklerin kontrol ettiği gelirin artmasının hane harcamalarını özellikle de çocuklara yönelik harcamaları nasıl etkileyebileceğini inceleyen bir çalışma mevcut değildir.

Bu çalışma Türkiyede hane üyeleri tarafından elde edilen gelirin birleştirilip birleştirilmediğini araştırmayı, gelirin kontrolünün kadınların veya erkeklerin elinde olmasının ve kadınların veya erkeklerin kontrol ettiği gelirin artmasının harcamaların hane içi dağılımı üzerindeki olası etkilerini incelemeyi amaçlamaktadır. Bu amaçla Mardin ve Muğla Merkez ilçesinde ikamet eden 408 evli çifte, 2010-2011 yılları arasında, bu çalışma için özel olarak oluşturulan anket uygulanmış ve Türkiye literatüründeki bu boşluğun doldurulması hedeflenmiştir.

Üç bölümden oluşan çalışmanın birinci bölümünde hane içerisinde gelirin nasıl bölüşüldügünü ve hanehalkı gelir kaynaklarının harcama kalıplarını etkileyip etkilemediğini incelemek üzere hanehalkı davranışlarının teorik modellerinden üniter ve kolektif modeller kısaca özetlenmiş ve söz konusu modellerin temel varsayımlarını test eden uygulamalı çalışmaların bulgularına yer verilmiştir. İkinci bölümde, Muğla ve Mardin alan araştırması bulguları üniter modelin gelir birleştirme hipotezi ve kolektif modelin pazarlık gücü yaklaşımı çerçevesinde incelenmiştir. Üçüncü ve son bölüm ise genel değerlendirme ve politika önerilerine ayrılmıştır.

\section{Hanehalkı Davranışının İncelenmesi: Üniter ve Kolektif Model}

Hanehalkı davranışlarına ilişkin teorik modeller, hanehalkı gelir kaynaklarının ve bu geliri kimin kazandığının harcama kalıplarını etkileyip etkilemediğine ilişkin varsayımları dolayısıyla üniter model ve kolektif model olmak üzere ikiye ayrılmaktadır. Çalışmada üniter model gelir birleştirme yaklaşımı, kolektif model ise pazarlık gücü yaklaşımı çerçevesinde ele alınmıştır.

\section{I. Üniter Model ve Gelir Birleştirme Yaklaşımı}

Hanehalkı davranışlarını analiz eden iktisatçılar geleneksel olarak hanehalkının tek bir birim olarak davrandığını varsaymakta ve hanehalkını, ortak refahın maksimize edilmesi için kaynakların dağılımı, zamanın dağıtımı ve piyasadan malların satın alınması gibi konular üzerinde mutabık olan bireylerin toplamı olarak ele almaktadır. Bu yaklaşım literatürde üniter hanehalkı modeli ${ }^{6}$ olarak adlandırılmaktadır ${ }^{7}$. Üniter hanehalkı modeline göre hane üyeleri

5 Thomas, 1990. Thomas, 1992. Hoddinott, J., Haddad, L. (1995), Does Female Income Share Influence Household Expenditures?, Evidence from Cote d'Ivoire, Oxford Bulletin of Economics and Statistics, 57(1): 77-96.

6 Üniter hanehalkı modeli literatürde "neoklasik hanehalkı modeli", "ortak tercih modeli", "ortak aile fayda modeli", "fedakâr (altruistic) model” veya "iyiliksever diktatör modeli (benevolent dictator)" olarak çeşitli şekillerde adlandırılmakla birlikte çalışmada aynı şeyi ifade etmek üzere üniter model kavramının kullanımı tercih edilmiştir.

7 Adam, C. ve diğerleri (2003). "Dynamic Intrahousehold Bargaining, Matrimonial Property Law and Suicide in Canada", Household Decisions, Gender and Development: A Synthesis of Recent Research, Derleyen: Agnes R. Quisumbing, Washington, International Food Policy Research Institute, Johns Hopkins University Press, s. 37. 
gelirlerini birleştirmektedir. Eğer hane üyeleri gelirini birleştirir ve daha sonra refahı maksimize etmek için dağıtırsa, o zaman aynı hanedeki kadının ve erkeğin kontrolü altındaki gelir hanehalkı harcamaları üzerinde aynı etkiye sahip olacaktır ${ }^{8}$. Başka bir deyişle haneye kim tarafından ne kadar gelir getirildiği ve gelirin kim tarafından kontrol edildiği harcamaların hane içerisindeki dağılımını etkilemeyecektir ${ }^{9}$. Yine üniter modele göre aynı hanede yaşayan erkeğin gelirindeki ilave bir artış, kadının gelirindeki ilave bir artışla aynı şekilde harcanmaktadır ${ }^{10}$. Kısaca üniter model hanehalkı içerisindeki tüm bireylerin benzer tercihlere sahip olduğunu ve hanehalkı içerisindeki kararların, hanedeki her bir bireye aynı refah düzeyini sağlayacak şekilde alındığını varsaymaktadir $^{11}$.

Oysa son yıllarda hanehalkı davranışının analiz edilebilmesi için hanehalkının tek bir karar alma birimi olarak ele alındığı üniter modellerin yeterli olmadığına ilişkin çalışmaların sayısı artmaktadır. Çünkü hanehalkının karar alma süreci karmaşık bir olaydır ${ }^{12}$ ve hanehalkları karar alırlarken tek bir kişi gibi davranmazlar. Yine çoğu durumda, kadınların ve erkeklerin sahip olduğu kaynaklar, hane harcamaları üzerinde aynı etkiye sahip değildir ${ }^{13}$. Üniter hanehalkı modeline gelen eleştiriler temelde iki konu üzerine odaklanmaktadır. Birincisi, üniter hanehalkı modelinin hane üyelerinin öncelik ve tercihlerde her zaman hemfikir oldukları varsayımının gerçeği iyi bir şekilde yansıtmadığıdır. Örneğin birçok hanede kadınların erkeklere göre daha yoksul olması ve kadınlara karşı hane içi şiddetin olduğu gerçeği, hane içerisinde alınan kararların ve harcamaların dağılımının aynı hanede yaşayan kadın ve erkeğe aynı refah düzeyini sağlamadığını göstermesi dolayısıyla hanehalkı davranışlarının üniter bakış açısına tezat teşkil etmektedir ${ }^{14}$. Üniter modele getirilen ikinci eleştiri ise üniter modelin temel varsayımlarından olan gelir birleştirme (income pooling) hipotezinin geçerliliği üzerinedir.

Gerek gelişmiş gerek gelişmekte olan birçok ülke için yapılan uygulamalı çalışmada üniter modelin geçerliliği sınanmıştır. Bu çalışmalarda üniter modelin geçerli olup olmadığı, gelir birleştirme hipotezinin reddedilip edilmediğine dayanmakta ve bu hipotezin reddedilmesi üniter modelin reddi anlamına gelmektedir. 1992 yılı verileri kullanılarak Kanada için yapılan bir çalışmada ${ }^{15}$, 14 harcama kategorisi için gelir birleştirme hipotezi test edilmiştir. Çalışma

8 Thomas, 1990.

9 Song, L. (2008). In Search of Gender Bias in Household Resource Allocation in Rural China, MPRA, 8348, http:// mpra.ub.uni-muenchen.de/8348, (Erişim Tarihi: 28. 07.2010).

10 Becker, 1991.

11 Kakwani, N., Son, H. H. (2006). Women's Earning Power and Wellbeing, UNDP, International Poverty Centre, 19, http://www.ipc-undp.org/pub/IPCOnePager19.pdf, (Erişim Tarihi: 11. 10. 2010).

12 Chiappori, P. A. (1997). “Collective Models of Household Behavior: The Sharing Rule Approach”, Intrahousehold Resource Allocation in Developing Countries: Models, Methods, and Policy, Derleyen: Haddad, L., Hoddinott, J., Alderman, H., Baltimore and London, Johns Hopkins University Press for the International Food Policy Research Institute, s. 39-52.

Quisumbing, A. R. (2003). "What Have We Learned from Research on Intrahousehold Allocation?", Household Decisions, Gender and Development: A Synthesis of Recent Research, Derleyen: A. R. Quisumbing, Washington, International Food Policy Research Institute, The Johns Hopkins University Press, s. 1-16.

14 Kakwani ve Son, 2006.

15 Phipps, S. A., Burton, P. S. (1998). What's Mine is Yours? The Influence of Male and Female Incomes on Patterns of 
sonucunda kadın ve erkeklerin gelirlerini barınma, hane giderleri (fatura), eğlence ve bağış gibi bazı tüketim kategorileri için birleştirmesine rağmen; diğer tüketim kategorileri için birleştirmediği ortaya çıkmıştır ${ }^{16}$. Kanada için yalnız kadınlar, yalnız erkekler ve sadece çiftlerden oluşan hanelerde çeşitli harcama kalemlerinin (gıda, restoran, fatura, kadın giyim, erkek giyim, ulaşım, eğlence ve sigara-alkol) dağılımının incelendiği başka bir çalışmada ${ }^{17}$ da, evli çiftler için üniter modelin gelir birleştirme hipotezi reddedilmiştir. Gelir birleştirme hipotezini Avustralya için test eden çalışmada ${ }^{18}$ gelirin barınma ve ulaşım harcamaları için birleştirildiği, giyim harcamaları için ise birleştirilmediği sonucuna ulaşılmıştır. Ayrıca çalışmada yaşlı bireylerin gelir birleştirme olasılığının gençlere göre daha düşük olduğu da tespit edilmiştir. Fransa için 1985 verileri kullanılarak yapılan çalışmada ${ }^{19}$ ise kadın giyim, erkek giyim, gıda, restoran, sağlık, tatil, kozmetik, kitap/müzik ve eğlence harcamaları için gelir birleştirme hipotezi reddedilmiştir.

Üniter modelin geçerli olup olmadığg gelişmekte olan birçok ülke için de sinanmıştır. Brezilya için yapılan çalışmalarda ${ }^{20}$, kadınların ve erkeklerin gelirlerinin özellikle sağlık, eğitim ve boş zaman gibi hanehalkı harcamaları üzerinde farklı etkilere sahip olduğu tespit edilerek üniter modelin gelir birleştirme hipotezi reddedilmiştir. Gelişmekte olan diğer ülkeler için de benzer sonuçlar bulunmuştur. Tayvan için 1980 yılı verileri kullanılarak yapılan çalışmada ${ }^{21}$ on mal grubundan dördü için gelir birleştirme hipotezi reddedilirken; Meksika ${ }^{22}$ ve Bangladeş ${ }^{23}$ için yapılan çalışmalarda da gelir birleştirme hipotezi dolayısıyla üniter model reddedilmiştir.

Uluslararası literatürün ortaya koyduğu üzere gerek gelişmiş gerek gelişmekte olan ülkelerde farklı yıllar için yapılan çalışmalar genel olarak üniter modelin gelir birleştirme hipotezinin reddedildiğini göstermektedir. Uluslar arası literatür bu noktada, kolektif modelin temel varsayımı olan pazarlık gücünün harcamaların hane içi dağılımını etkileyip etkilemediği üzerine odaklanmış ve birçok ülke için bu hipotezin geçerli olup olmadığı test edilmiştir.

Household Expenditure, Economica, 65(260): 599-613.

16 Çalışmada ele alınan harcama kalemleri, restoran, gıda, barınma, kadın giyim, erkek giyim, çocuk giyim, çocuk bakım, hane geçindirme giderleri (fatura), eğlence/boş zaman, bağış, ulaşım ve içki-sigara harcamalarıdır.

17 Browning, M., Chiappori, P. A. (1998). Efficient Intra-Housohold Allocations: A General Characterization and Empirical Tests, Econometrica, 66(6): 1241-1278.

18 Lancaster, G., Ray, R. (2002). Tests of Income Pooling on Household Budget Data: The Australian Evidence, Australian Economic Papers, (41): 99-114.

19 Bourguignon ve diğerleri, 1993.

20 Thomas, 1990. Thomas, 1992.

21 Thomas, D., Chen, C. L. (1994). Income Shares and Shares of Income: Empirical Tests of Models of Household Resource Allocations, RAND Labor and Population Program Working Paper Series, s. 94-108, http://www.rand.org/ pubs/drafts/2005/DRU705.pdf, (Erişim Tarihi: 12. 08. 2011).

22 Attanasio, O., Lechene, V. (2002). Tests of Income Pooling in Household Decisions, Review of Economic Dynamics, (5): 720-748.

23 Quisumbing, A. R., de la Brière, B. (2000). Women's Assets and Intrahousehold Allocation in Rural Bangladesh: Testing Measures of Bargaining Power, IFPRI FCND Discussion Paper, 86. 


\subsection{Kolektif Model ve Hane İçi Pazarlık Gücü Göstergesi Olarak Bireysel Gelir}

Eğer üniter hanehalkı modeli geçerli olsaydı ve tüm hanehalkı gelirini birleştirip daha sonra hane refahını maksimize etmek için çeşitli harcamalar arasında dağıtsaydı; o zaman hane gelirini kimin kontrol ettiği önemsiz bir konu olacaktı. Oysa uluslararası literatürün de ortaya koyduğu üzere, üniter hanehalkı modeli ve gelir birleştirme hipotezi birçok ülkede reddedilmiştir. Bu anlamda kadınların ve erkeklerin hane geliri üzerindeki kontrollerinin farklı etkilerinin olması ve kontrol ettikleri gelirin artmasının hanedeki bireylerin tüketim kalıplarını ve refahlarını etkilemesi beklenmektedir. Bu noktada üniter hanehalkı modelinin gelir birleştirme hipotezinin reddedilmesi üzerine alternatif olarak kolektif hanehalkı modeli geliştirilmiştir. Kolektif modeller, genel olarak farklı hane üyelerinin farklı tercihlere, farklı "hane içi pazarlık güçlerine” ve söz konusu unsurların etkileşiminin bir sonucu olarak hane içinde farklı harcama dağılımı sonuçlarına sahip olduklarını varsaymaktadır ${ }^{24}$. Ayrıca, hanehalkı davranışının kolektif modelleri kadın ve erkeğin gelirlerinin mutlaka aynı şekilde bölüştürülmeyeceğini belirtmektedir ${ }^{25}$.

Kolektif hanehalkı modeli, harcamaların hane içi dağılımının, bireylerin hane içerisindeki pazarlık güçlerine bağlı olduğunu öngörmektedir ${ }^{26}$. Kolektif modelin pazarlık gücü yaklaşımına göre, hane içi pazarlık gücünün temel belirleyicileri servet ${ }^{27}$, transfer ödemeleri ve sosyal yardım ${ }^{28}$, eğitim ${ }^{29}$, pazarlık gücü endeksi ${ }^{30}$ ve bireysel gelirdir. Ancak çalışmanın ana konusunu gelirin kontrolünün harcama kalıpları üzerindeki olası etkileri oluşturduğu için çalışmada sadece hane içi pazarlık gücü göstergesi olarak bireysel geliri dikkate alan uluslararası literatür incelenmiştir.

Hane içi pazarlık gücü yaklaşımına göre, bireylerin kazanma güçlerinin artması onlara hane içi kararlarda daha fazla pazarlık gücü vermektedir ${ }^{31}$. Buradan hareketle, kadınların hane gelirine olan katkıları ve dolayısıyla bireysel geliri arttıkça, hanehalkı kaynaklarının nasıl paylaştırılacağını etkileme güçlerinin de artacağı beklenmektedir. Kadınların hane gelirine olan katkıları ise, ücretli istihdam olanaklarının az olmasından ve işgücü piyasasında ücretler açısından yaşamış oldukları toplumsal cinsiyet eşitsizliğinden dolayı erkeklere göre daha azdır ${ }^{32}$

24 Manser ve Brown, 1980. McElroy ve Horney, 1981.

25 Phipps ve Burton, 1998.

26 Frankenberg, E., Thomas, D. (2003). "Measuring Power", Household Decisions, Gender and Development: A Synthesis of Recent Research, Derleyen: A. R. Quisumbing, Washington DC, International Food Policy Research Institute, Johns Hopkins University Press, s. 29-36.

27 Quisumbing ve de la Briere, 2000. Razzaque, M. A., Ahsanuzzaman, A. (2009). Intrahousehold Resource Allocation and Women's Bargaining Power: New Evidence from Bangladesh, file://C:/Users/samsung/Downloads/SSRNid1550559.pdf, (Erişim Tarihi: 21.03.2015).

28 Lundberg, S. J. ve diğerleri (1997). Do Husbands and Wives Pool Their Resources? Evidence from the United Kingdom Child Benefit, The Journal of Human Resources, 32(3): 463-480. WardBatts, J. (2008). Out of the Wallet and into the Purse: Using Micro Data to Test Income Pooling, Journal of Human Resources, (43): 325-351.

29 Song, 2008. Quisumbing, A. R. (1994). Intergenerational Transfers in Philippine Rice Villages: Gender Differences in Traditional Inheritance Customs, Journal of Development Economics, 43(2): 167-95.

30 Razzaque ve Ahsanuzzaman, 2009. Türkiye için hesaplanan pazarlık gücü endeksi için bakınız: Ekiz Gökmen, Ç., Gökovalı, U. (2016). Hane İçine Gizlenen Kadın Yoksulluğu: Muğla-Mardin Örneği, ODTÜ Gelişme Dergisi, 43(1): 157-190.

31 Kakwani ve Son, 2006.

32 Selim, R., İlkkaracan, İ. (2002). Gender Inequalities in the Labor Market in Turkey: Differentials in Wages, Industrial 
ve genellikle evde yaptıkları ücretsiz işler yoluyla gerçekleşmektedir. Ancak kadınların ücretsiz ev işleri, hanehalkı refahı açısından kritik bir önem taşımasına rağmen, ne yazık ki ücretli çalışma kadar takdir edilmemektedir. Bu durum kadınların hane içi pazarlık güçlerinin erkeklere göre daha az olmasina neden olmaktadir.

Pazarlık gücüne ilişkin literatür sahip olunan gelirin bireylerin hanehalkı harcamaları üzerindeki pazarlık gücünü ve dolayısıyla harcamaların hane içerisindeki dağılımını etkilediğini ortaya koymaktadır. Brezilya için yapılan bir çalışmanın sonuçlarına ${ }^{33}$ göre, kadın ve erkek arasında okullaşma oranı, işgücüne katılım oranı ve çalışma saatlerinde yaşanan eşitsizlikler dolayısıyla para kazanma konusunda eşitsizlikler bulunmakta ve bireysel gelir düzeyinde yaşanan eşitsizlikler kadınların hane içi pazarlık güçlerinin erkeklerinkinden daha az olmasına neden olmaktadır. İsviçre için yapılan çalışmada ${ }^{34}$, hane içinde eşit olmayan pazarlık gücünün eşlerin hane gelirine yaptıkları katkıya bağlı olduğu; bunun da harcamaların hane içi dağılımını etkilediği bulunmuştur. Fransa için yapılan çalışma ${ }^{35}$ sonucunda da benzer şekilde eşlerin göreceli gelirlerinin, toplam gelir sabit olduğunda bile hane içerisindeki tüketim yapılarını etkilediği tespit edilmiştir. Kanada için yapılan çalışmada ${ }^{36}$ ise, eşlerin her birine yapılan giyim harcamalarının nihai dağılımının eşlerin göreceli gelirlerine, yaşlarına ve yaşam boyu servetlerine bağlı olduğu tespit edilmiştir. Yine çalışma sonuçlarına göre, toplam hane geliri içerisinde kadınların gelirinin payının sadece \%25 olduğu yoksul bir hanehalkında, kadınlar toplam harcamaların sadece \%42'sini alırken, toplam hane geliri içerisinde kadınların gelirinin payının \%75 olduğu zengin bir hanehalkında kadınlar toplam harcamaların \%58'ini almaktadır. Bu sonuçlar gelir farklılıklarının harcamaların hane içerisindeki dağılımı üzerindeki etkilerinin oldukça önemli olduğunu ortaya koymakla birlikte, kadınların gelir artışının aynı oranda harcama artışına neden olmadığını da göstermektedir.

Hane içi pazarlık gücünün artmasının etkilerine ilişkin literatürün önemli bir kısmı, gerek gelişmiş gerek gelişmekte olan ülkelerde kadınların kontrol ettiği gelirdeki artışlar sonucu harcamaların hane içerisindeki dağılımının daha çocuk merkezli bir hale geldiği ve dolayısıyla çocuklar lehine yapılan harcamaların artarak çocukların refahında iyileşme olduğu konusuna odaklanmaktadır. İngiltere için yapılan çalışmalarda ${ }^{37}$ kadınların kontrol ettiği gelirin artmasının, giyim ve sigara gibi erkeklere yapılan harcamaları azalttığı; çocuk giyim, oyuncak, harçlık ve restoran gibi kadınlar ve çocuklara yapilan harcamaları ise arttırdığı tespit edilmiştir. Kanada için yapılan bir çalışma ${ }^{38}$ da kadınların geliri ve dolayısıyla pazarlık gücü arttığında çocuk bakım harcamalarının arttığını; ancak erkeklerin geliri arttığında böyle bir durumun söz konusu olmadığını ortaya koymuştur.

\& Occupational Distribution of Men and Women, http://content.csbs.utah.edu/ ehrbar/erc2002/pdf/P405.pdf, (Erişim Tarihi: 05.12.2009).

33 Kakwani ve Son, 2006.

34 Bütikofer, A. ve diğerleri (2009). Income Pooling and the Distribution of Individual Consumption among Couples in Switzerland, Working Papers, http://staff.vwi.unibe.ch/gerfin/downloads/poolingsharing_oct09.pdf, (Erişim Tarihi: 07.02.2011).

35 Bourguignon ve diğerleri, 1993.

36 Browning ve diğerleri, 1994.

37 Lundberg ve diğerleri, 1997. WardBatts, 2008.

38 Phipps ve Burton, 1998. 
Gelişmekte olan ülkeler için yapılan çalışmalarda da benzer bulgular elde edilmiştir. Brezilya için yapılan çalışmaların ${ }^{39}$ sonuçlarına göre, gelirin kadınların kontrolünde olması, erkeklerin kontrolünde olması durumuna göre hane üyelerinin sağlı̆̆ını daha olumlu etkilemekte ve çocukların yaşama şansını 20 kat daha arttırmaktadır. Yine erkeklere göre kadınların sahip olduğu gelir arttıkça hane bütçesinden boş vakit harcamalarına (eğlence ve törenler) ve çocuklara yapılan beşeri sermaye harcamalarına (sağlık ve eğitim) ayrılan pay da artmaktadır. Côted'Ivoire için yapılan çalışmada ${ }^{40}$, kadınların kontrolündeki gelirin iki katına çıkmasının, bütçeden gıdaya ayrılan payda \%2'lik bir artışa, alkole ve sigaraya ayrılan payda ise sırasıyla \%26 ve \%14 gibi önemli bir azalışa neden olduğu tespit edilmiştir. Bangladeş, Endonezya, Etiyopya ve Güney Afrika için yapılan çalışmada ise kadınların kontrol ettiği gelirin göreli olarak daha yüksek olmasının, eğitim ve çocuk giyim harcamalarının bütçedeki payını arttırdığı bulunmuştur ${ }^{41}$. Bangladeş için yapılan başka bir çalışmada da benzer şekilde kadınların varlıklarının çocuk giyim ve eğitim harcamalarının payını, erkeklerin varlıklarının ise gıda harcamalarının payını pozitif bir şekilde etkilediği tespit edilmiştir ${ }^{42}$. Etiyopya'da kadınların ekonomik pozisyonunun daha iyi olmasının çocuklarına yapılan gıda harcaması üzerinde pozitif bir etkiye sahip olduğu bulunmuştur ${ }^{43}$.

Uluslararası literatüründe ortaya koyduğu üzere, kolektif hanehalkı modelinde, harcamaların hane içerisindeki dağılımı pazarlık gücünün göstergelerinden biri olan bireysel gelir tarafından belirlenmektedir. Bu durumda erkeklerle karşılaştırıldıklarında daha az kişisel gelire sahip olan kadınların hane harcamaları üzerindeki kontrolünün, başka bir deyişle pazarlık gücünün de daha az olduğu bir gerçektir. Türkiyede gelirin kontrolünün kadınların elinde olmasının hane harcamalarının dağılımı üzerindeki olası etkilerinin farklı sosyo-ekonomik özelliklere göre değişip değişmediğini ortaya koymayı amaçlayan bu çalışmanın gelinen bu aşamasında Muğla ve Mardin'de gerçekleştirilen alan araştırması bulgularına değinilecektir.

\section{Alan Araştırması ve Bulguları}

\section{I. Araştırmanın Kapsamı, Örneklem Büyüklüğü Seçimi ve Veri Toplama Süreci}

Alan araştırması 2010-2011 tarihleri arasında Mardin ve Muğla Merkez ilçelerinde gerçekleştirilmiştir. Söz konusu iki ilin alan araştırması için seçilmesi sahip oldukları bir takım özelliklerden kaynaklanmaktadır. Mardin Türkiye ortalaması ile karşılaştırıldığında daha düşük kişi başı gelir düzeyine ${ }^{44}$, sosyo-ekonomik gelişmişlik düzeyine ve insani yoksulluk endeksine ${ }^{45}$

39 Thomas, 1990. Thomas, 1992.

40 Hoddinott ve Haddad, 1995.

41 Quisumbing, A. R., Maluccio, J. A. (2003). "Intrahousehold Allocation and Gender Relations: New Empirical Evidence from Four Developing Countries", Household Decisions, Gender and Development: A Synthesis of Recent Research, Derleyen: A. R. Quisumbing, Washington, International Food Policy Research Institute, The Johns Hopkins University Press, s. 23-28.

42 Quisumbing ve de la Brière, 2000.

43 Kimhi, A. (2004). Gender and Intrahousehold Food Allocation in Southern Ethiopia, The Center for Agricultural Economic Research Discussion Paper, No: 9.04.

44 TÜİK, (2012a). http://www.tuik.gov.tr/ulusalhesapapp/ulusalhesap.zul?tur=2, (Erişim Tarihi: 30.07.2012).

45 Çabuk, N. (2003). Güney Doğu Anadolu’da Yoksulluğun Sosyal Göstergeleri, Ankara Üniversitesi Dil ve Tarih 
sahipken Muğla, daha yüksek kişi başı gelir düzeyine ve sosyo-ekonomik gelişmişlik düzeyine sahiptir. Bireysel gelir düzeyinin en önemli belirleyicilerinden olan kadınların işgücüne katılım oranı açısından Mardin \%5 ile Türkiye sıralamasında en sondadır. Muğla'da ise kadınların işgücüne katılım oranı \%37 ile Türkiye ortalamasının $(27,6)$ üzerindedir ${ }^{46}$. Bu anlamda Türkiye’nin en yoksul coğrafi bölgesinde yer alan Mardin Türkiye’nin doğu bölümünün, Muğla ise batı bölümünün sosyo-ekonomik özelliklerini sergilemektedir.

Örneklem büyüklüğü Mardin ve Muğla ili Merkez ilçelerinin nüfuslarına göre hesaplanmış ve her iki ilde de yaklaşık olarak 191 hanenin (evli çiftin) anket için yeterli olduğu tespit edilmiştir ${ }^{47}$. Alan araştırması kapsamında Mardin Merkez ilçesinde 204 ve Muğla Merkez ilçesinde 204 olmak üzere toplam 408 evli çifte bu çalışma için özel olarak geliştirilen anket uygulanmıştır. Görüşmeciler tabakalı örneklem tekniği kullanılarak her iki ilin merkez ilçelerindeki tüm mahallelerinden (Mardin'de yirmi üç mahalleden Muğla'da ise on beş mahalleden) mahalle nüfusları ile orantılı olarak tesadüfî örneklem yöntemiyle seçilmiştir. Böylelikle farklı gelir grubundaki hanelere ulaşabilmek mümkün olmuştur. Anket, aynı hanedeki eşlere farklı odalarda uygulanmış ve böylelikle gelirin hane içi dağlımına ilişkin çok daha gerçekçi ve samimi cevaplar alınabilmiştir.

\subsection{Araştırma Bulguları}

Alan araştırması bulguları görüşmecilerin genel özelliklerinin tanıtılması, gelirin hane içerisindeki mevcut dağılımı ile gelirin kontrolünün kadınların veya erkeklerin elinde olmasının harcamaların hane içi dağılımı üzerindeki olası etkileri olmak üzere üç ana başlık altında incelenmiştir.

\subsection{Görüşmecilerin Genel Özellikleri}

Mardin ve Muğla’daki görüşmecilerin genel özelliklerine ilişkin özet bilgiler Tablo 1'de verilmiştir. Okullaşma süresi verilerinin de ortaya koyduğu üzere Türkiye genelinde ${ }^{48}$ olduğu gibi her iki ilde de kadınların eğitim düzeyi erkeklerden daha düşüktür. Ancak Mardin’de eğitime katılım açısından kadınların yaşamış oldukları eşitsizlikler daha fazladır. Bu durum Mardin'de kadınlar aleyhine var olan güçlü ataerkil yapı dolayısıyla kadınların eğitim hayatının dışında kalmalarının sonucu olarak değerlendirilebilir.

Coğrafya Fakültesi Dergisi, 43(2): 47.

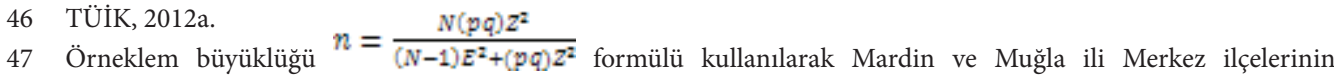
nüfuslarına göre (sırasıyla 88.054 ve 62.635) hesaplanmıştır. Burada N: araştırmanın içerdiği ana kütle büyüklüğünü; p: incelenecek olayın görülme olasılığını; q: incelenecek olayın görülmeme olasılığını (1-p); Z: belirli serbestlik derecesinde ve saptanan yanılma düzeyinde $\mathrm{Z}$ tablosunda bulunan teorik değeri; E: olayın görülüş sıklığına göre yapılmak istenen \pm sapmayı $(0,05)$ simgelemektedir.

48 Türkiye genelinde 2010 yılı itibariyle okuryazar olmayan kadınların oranı \%13,9, erkeklerin oranı ise \%3,1'dir. Ayrıntılı bilgi için bakınız: TÜIK, (2012b). İstatistiklerle Kadın 2011, Women in Statistics, Türkiye İstatistik Kurumu Matbaası, Ankara, s. 25-26. 
Mardin'de kadınların işgücüne katılım oranları eğitim seviyelerinin düşüklüğü ile bağlantılı olarak oldukça düşüktür. Mardin'de kadın görüşmecilerin \%87'si, erkek görüşmecilerin ise $\% 12$ 'si işgücü piyasasına dâhil değildir ${ }^{49}$. Söz konusu veriler Türkiye ortalamasından oldukça yüksektir ${ }^{50}$. Muğla’da da işgücüne katılım oranı açısından kadınlar aleyhine eşitsiz bir durum olmasına rağmen, söz konusu eşitsizlik Mardin’deki kadar yüksek değildir. Muğla’da kadın görüşmecinin \%46'sı, erkek görüşmecilerin ise \%17'si işgücü piyasasına dâhil değildir ${ }^{51}$. Tablodan görülmemekle birlikte her iki ilde de çocuk ve hasta bakımı, eş ve ailelerin izin vermemesi ve ev içi sorumluluklar kadınların çalışmasına engel olan en önemli faktörlerdir ${ }^{52}$. Söz konusu bulgular eğitim ve işgücü piyasasına katılımda yaşanan cinsiyet eşitsizliklerinin temelde "kadının yeri evi ve görevinin de annelik olduğuna" ilişkin ataerkil düşünce yapısından ${ }^{53}$ ve bunun sonucu kadınlara atfedilen ev içi sorumluluklarından kaynaklandığ ${ }_{1} 54$ görüşünü desteklemektedir.

Mardin'de işgücü piyasasına dâhil olan az sayıda kadın genellikle kamu sektöründe (26 kadının 16’sı) çalışmaktadır. Bu durum bölgedeki ataerkil yapı dolayısıyla kadınların işgücü piyasasına katılımlarının erkeklerin otoritesini sarsmayacak biçimde gerçekleşmesinin ${ }^{55}$ bir sonucu olarak değerlendirilebilir. Erkekler ise genel itibariyle özel sektörde (179 erkeğin 144’ü) çalışmaktadır. Ataerkil yapının nispeten baskın olmadığı Muğla’da ise kadın (110 kadının 62'si) ve erkekler (169 erkeğin ise 108’i) daha ziyade özel sektörde çalışmaktadır. Mardin'de kadınların ortalama çalışma süresi yaklaşık 1 yıl iken, bu süre erkeklerde 16 yıldır. Muğla'da ise ortalama çalışma süresi kadınlarda yaklaşık 7 yıl, erkeklerde 18 yıldır.

Kısaca özetlenecek olursa, her iki ilde de (özellikle Mardin’de) kadınların okullaşma süreleri, işgücüne katılım oranları ve ortalama çalışma süreleri erkeklere göre daha düşüktür. Söz konusu alanlarda yaşanan cinsiyet eşitsizlikleri ise bireysel gelir düzeyi eşitsizliklerinin ardında yatan temel faktördür. Çünkü kadınların eğitim düzeyinin düşük olması bir yandan işgücüne katılım oranını belirlerken diğer yandan işgücüne katıldığı takdirde daha az gelir elde etmesine neden olmaktadır. Bireysel gelir düzeyi eşitsizliklerine neden olan faktörler, görüşmecilerin genel özelliklerini sunan Tablo 1 yardımıyla ortaya koyulduktan sonra, çalışmanın gelinen bu

49 Emekli olduğu için çalışmayanları toplamdan düştüğümüzde, Mardin’de kadınların (çalışmayanların sadece 3 tanesi emeklidir) \%85,8'i erkeklerin ise (çalışmayanların 16’sı emeklidir) \%4,4’ü işgücüne dâhil değildir.

502011 yılı itibariyle Türkiye genelinde kadınların işsizlik oranı \%11,3’dir. Bakınız TÜİK, 2012b:93-102.

51 Emekli olduğu için çalışmayanları toplamdan düştüğümüzde (çalışmayanların sadece 18 tanesi emeklidir), Muğla’da kadınların \%37,3’ü çeşitli nedenlerle işgücü piyasasına dâhil değildirler. Çalışmadığını beyan eden erkeklerin ise tamamı emeklidir. Başka bir deyişle Muğla’daki erkek görüşmecilerin tamamı ya halen çalışmakta ya da zamanında işgücü piyasasına dâhil olmuşlardır.

52 Ayrıntılı bilgi için bakınız, Gökovalı, U. ve diğerleri (2014). "Kadın Yoksulluğuna Objektif ve Subjektif Bakış: Muğla ve Mardin Örneği”, Yoksulluk ve Kadın, Derleyen: Topçuoğlu A. ve diğerleri, İstanbul, Ayrıntı Yayınları, s. 354-355.

53 Sallan Gül, S. (2005). Türkiye’de Yoksulluğun Kadınsılaşması, Amme İdaresi Dergisi, 38(1): 25-45.

54 Adaman, F., Keyder, Ç. (2006). Türkiye’de Büyük Kentlerin Gecekondu ve Çöküntü Mahallelerinde Yaşanan Yoksulluk ve Sosyal Dişlanma, http://ec.europa.eu/employment_social/social_inclusion/docs/2006/study_ turkey_tr.pdf, (Erişim Tarihi: 31.10.2008). Kiren Gürler, Ö., Üçdoğruk, Ş. (2007). Türkiye’de Cinsiyete Göre Gelir Farklılı̆̆ının Ayrıştırma Yöntemiyle Uygulanması, Journal of Yaşar University, 2(6): 571-589.

55 Toksöz, G. (2012). "Neoliberal Piyasa, Özel ve Kamusal Ataerki Çıkmazında Kadın Emeği”, Türkiye’de Refah Devleti ve Kadın, Derleyen: Dedeoğlu, S., Elveren, A. Y. İstanbul, İletişim Yayınları, s. 103. 
aşamasında aynı hanede yaşayan bireylerin gelirlerini birleştirip birleştirmediği ve dolayısıyla üniter modelin gelir birleştirme hipotezinin geçerli olup olmadığı araştırılacaktır.

Tablo I: Görüşmecilerin Genel Özellikleri: Mardin - Muğla

\begin{tabular}{|c|c|c|c|c|c|c|}
\hline & \multicolumn{3}{|c|}{ Mardin } & \multicolumn{3}{|l|}{ Muğla } \\
\hline & $\begin{array}{l}\text { Kadın } \\
(204)\end{array}$ & Erkek (204) & Toplam (408) & \begin{tabular}{|l|} 
Kadın \\
$(204)$
\end{tabular} & Erkek (204) & \begin{tabular}{|l} 
Toplam \\
$\mathbf{( 4 0 8 )}$
\end{tabular} \\
\hline Okullaşma Süresi (yıl) & 5,9 & 8,4 & 7,2 & 9,9 & 10,8 & 10,4 \\
\hline \multicolumn{7}{|l|}{ Çalışma Durumu } \\
\hline Çalışmıyor & \begin{tabular}{|l|}
178 \\
$(87,3)$
\end{tabular} & \begin{tabular}{|l|}
25 \\
$(12,3)$ \\
\end{tabular} & $\begin{array}{l}203 \\
(49,8)\end{array}$ & \begin{tabular}{|l|}
94 \\
$(46,1)$
\end{tabular} & \begin{tabular}{|l|}
35 \\
$(17,2)$
\end{tabular} & $\begin{array}{l}129 \\
(31,6)\end{array}$ \\
\hline Çalışıyor & \begin{tabular}{|l|}
26 \\
$(12,8)$
\end{tabular} & \begin{tabular}{|l|}
179 \\
$(87,8)$
\end{tabular} & $\begin{array}{l}205 \\
(50,3)\end{array}$ & $\begin{array}{l}110 \\
(53,9)\end{array}$ & \begin{tabular}{|l|}
169 \\
$(82,8)$
\end{tabular} & $\begin{array}{l}279 \\
(68,4)\end{array}$ \\
\hline \multicolumn{7}{|l|}{ Çalışılan Sektör } \\
\hline Kamu & 16 & 35 & 51 & 48 & 61 & 109 \\
\hline Özel & 10 & 144 & 154 & 62 & 108 & 170 \\
\hline Çalışma Süresi (yıl) & 1,2 & 16,1 & 8,7 & 7,3 & 18,4 & 12,8 \\
\hline
\end{tabular}

Not: Parantez içerisindeki değerler yüzde değerleri göstermektedir.

\subsubsection{Gelir Birleştirme Yaklaşımı ve Gelirin Hane İçerisindeki Dağılımı 56}

Üniter modelin geçerliliğini araştırmak amacıyla çalışmada Mardin ve Muğla'daki hanehalklarının gelir düzeyi, hane üyeleri tarafından kazanılan gelirin birleștirilip birleştirilmediği, birleştirilen gelirden yapılan harcamalar ve gelirin hane içi bölüşümü Tablo 2 yardımıyla incelenmiştir. Çalışmada aynı hanede yaşayan hem kadın hem de erkeğe anket uygulandığg için haneye ilişkin olarak elde edilen bilgiler hem kadın, hem de erkek için ayrı ayrı değerlendirilmiştir.

Bireyler arasında para kazanma konusunda yaşanan eşitsizlikleri temelde okullaşma oranı, işgücüne katılım oranı ve ortalama çalışma süresi belirlemektedir. Bu anlamda Mardin'de görüşmecilerin bireysel gelir düzeyleri ve dolayısıyla hane gelirleri söz konusu faktörlere bağlı olarak Muğla'daki görüşmecilerden daha düşüktür. Yine Mardin'de kadınlar aleyhine daha yüksek oranda seyreden eşitsizlikler dolayısıyla kadın ve erkeklerin ortalama bireysel gelir düzeyleri arasındaki fark daha fazladır. Mardin'de erkeklerin aylık ortalama bireysel gelirleri kadınların ortalama aylık bireysel gelirlerinden yaklaşık dokuz kat daha fazla iken; Muğla'da kadın ve erkeklerin aylık ortalama bireysel gelirleri arasındaki fark iki kattır ${ }^{57}$. Toplam hane geliri içerisinde kadınların gelirinin payı, yapılan uluslararası çalışmaların bulgularını destekler

56 Bu alt bölüme ilişkin alan bulguları daha sınırlı bir şekilde daha önce Ekiz Gökmen ve Gökovalı, 2016:168-170'de paylaşılmıştır.

57 Tabloda sunulan ortalama aylık bireysel gelir düzeyine ilişkin veriler bireysel gelir toplamının toplam katılımcı sayısına oranlanması ile elde edilmiştir. Tablodan görülmemekle birlikte Mardin’de işgücü piyasasına katılan kadınların (26) aylık ortalama bireysel gelirleri yaklaşık 998 TL iken, Muğla’da işgücü piyasasına katılan kadınların (110) ise aylık ortalama bireysel gelirleri 1.325 TL'dir. 
şekilde ${ }^{58}$ oldukça düşüktür. Geniş aile yapısının gözlemlendiği Mardin'de ${ }^{59}$ toplam hanehalkı geliri ${ }^{60}$ içerisinde kadınların gelirinin payı sadece \%8,4 iken, Muğla'da \%28,9'dur. Bunun haricinde toplam hane gelirleri arasında Mardin ${ }^{61}$ ve Muğla ${ }^{62}$ arasında önemli bir fark olmakla birlikte ${ }^{63}$, hane büyüklügü dikkate alındığında bu fark - eşit paylaşım varsayımı altında bile - kişi başına düşen gelir (Mardin'de yaklaşık 1.748/5=350 TL, Muğla’da 2.911/3=970 TL) ve dolayısıyla bireylerin yaşam standardı açısından değerlendirildiğinde daha önemli hale gelmektedir. Hane içerisinde gelirin eşit bir şekilde paylaşıldığı varsayımı altında Mardin'de kalabalık hanelerde yaşayan kadınların hane gelirinden aldıkları payın, Muğla'daki kadınlardan daha düşük olduğunu söylemek yanlış olmayacaktır.

Hane davranışlarını inceleyen kolektif modeller, üniter modelin gelir birleştirme hipotezini çürüterek, hane üyelerinin genel itibariyle gelirlerini birleştirmediklerini ortaya koymuştur. Çalışmada üniter modelin gelir birleştirme yaklaşımının geçerliliği Tablo 2 yardımıyla incelenmiştir. Tablo 2’ye göre Mardin'deki hanelerin büyük bir çoğunluğunda (yaklaşık \%72) gelir birleştirilmemektedir. Bu durum Mardin'de kadınların önemli bir kısmının (170 kadın) Türkiye geneline benzer şekilde ${ }^{64}$ bireysel gelire sahip olmamasından kaynaklanabilir. Muğla’da ise Mardin’e kıyasla gelirin birleştirildiğini ifade eden bireylerin sayısı daha fazladır. Yine de Muğla'da da eşlerin \%41'i gelirin birleştirilmediğini beyan etmişlerdir. Mardin'de haneye giren gelirin birleştirildiğini ifade eden 116, Muğla'da ise 241 görüşmeci bulunmaktadır. Her iki ilde de gelirin birleştirildiğini ifade eden görüşmecilerin büyük bir çoğunluğu gelirin kira-faturalar, gıda, sağlık ve giyim harcaması gibi hane harcamaları içerisinde nispeten daha yüksek bir paya sahip olan harcama kalemleri için birleştirildiğini beyan etmişlerdir. Hane harcamaları içerisinde nispeten daha az paya sahip olan eğitim, eğlence ve alkol-sigara harcamaları için

58 Yapılan uluslararası çalışmalarda da evli Fransız, İngiliz, Amerikalı ve Alman kadınların yaklaşık 1/4'ünün, evli İtalyan kadınların ise yaklaşık yarısının toplam hane gelirinin 1/10’undan daha azını aldığı tespit edilmiştir. Ayrıntılı bilgi için bakınız: Goldberg, G. S. (2010): 278-279.

Ortalama hanehalkı büyüklüğü Mardin'de beş, Muğla'da üçtür.

60 Toplam hane geliri olarak eşlerin beyanlarının ortalaması, kadınların bireysel gelir düzeyi olarak da kendi beyanları dikkate alınmıştır.

61 Mardin'de kadın görüşmeciler aylık ortalama hane gelirinin yaklaşık 1.637 TL olduğunu erkek görüşmeciler ise, $1.858 \mathrm{TL}$ olduğunu beyan etmişlerdir. Bu konuda erkek görüşmecilerin daha sağlıklı bilgi verdiği söylenebilir. Tablodan görülmemekle birlikte kadın görüşmecilerin 42'si haneye giren toplam aylık gelirin yaklaşık olarak ne kadar olduğunu bilmediğini ifade etmiştir.

62 Muğla’da ise kadın ve erkek görüşmecilerin toplam hane gelirine ilişkin beyanları (sırasıyla 2.914 TL ve 2.908 TL) neredeyse aynıdır. Muğla’da haneye giren toplam aylık gelirin yaklaşık olarak ne kadar olduğunu bilmediğini ifade eden sadece 13 kadın vardır.

63 Her iki ilde toplam aylık hane gelirinin ne kadar olduğunu bilemediklerini ifade eden toplam 55 kadından 6 tanesi, toplam hane gelirine ilişkin yaklaşık bir değer de beyan edememiştir. Ancak toplam hane gelirlerinin sıfır olarak girilmesi hem veri setinden dışlanmalarına, hem de ortalama hane geliri değerinin gerçek değerinden sapmasına neden olacağından, bu kadınlar için toplam hanehalkı geliri değeri olarak eşlerinin beyan ettiği gelir değerleri esas alınmıştır.

64 Türkiye'de 2008 yılı itibariyle işgücüne katılımda yaşanan cinsiyet eşitsizliğine bağlı olarak çalışabilir yaştaki kadınların \%62,5’nin herhangi bir kişisel geliri bulunmamaktadır. Erkeklerde aynı oran sadece \%5,4’tür. Ayrıntılı bilgi için bakınız: Dayığlu, M., Başlevent, C. (2012). “Türkiye’de Gelir Dağılımının ve Yoksulluğun Toplumsal Boyutları”, Türkiye'de Refah Devleti ve Kadın, Derleyen: S. Dedeoğlu, A. Y. Elveren, İstanbul, İletişim Yayınları, s.127-157. 
gelirin birleştirildiğini beyan eden görüşmecilerin sayısı ise daha azdır. Genel itibariyle her iki ilde de birleştirilen gelirden yapılan harcamalara ilişkin kadın ve erkeklerin beyanlarının benzeştiği söylenebilir. Eşlerin beyanları arasındaki en önemli farklılık Mardin’de alkol-sigara harcamasına ilişkindir. Mardin’de gelirin birleştirildiğini ifade eden kadınların yaklaşık \%61’i hane gelirinin alkol ve sigara harcaması için birleştirildiğini belirtirken; erkeklerde bu oran sadece \%42'dir. Alan araştırması esnasında edinilen izlenimler, Mardin'de kadınların en çok eşlerinin alkol-sigara harcamasından şikâyetçi oldukları yönündeydi. Bu durum erkeklerin görece daha az bir oranının söz konusu harcama kalemi için hane gelirinin birleștirildiğini ifade etmelerinin bir nedeni olabilir. Tüm bu veriler ışığında üniter modelin gelir birleştirme hipotezinin özellikle Mardin için reddedilmesinin mümkün olduğunu; Muğla için ise sadece hane harcamaları içerisinde nispeten daha yüksek paya sahip olan kira-faturalar, gıda, giyim ve sağlık gibi bazı harcama kalemleri için reddedilmesinin mümkün olmadığını söylemek yanlış olmayacaktır. Üniter modelin gelir birleştirme yaklaşımına ilişkin bu bulgu, uluslararası literatür bulgularını desteklemektedir.

Uluslararası literatürün ortaya koyduğu üzere hane üyeleri gelirini birleştirse bile hane geliri üyeler arasında eşit bir şekilde paylaşılmamakta ve paylaşım genellikle kadınlar aleyhine gerçekleşmektedir. Uluslararası literatür bulguları doğrultusunda eşit paylaşım varsayımının kaldırılması durumunda, Mardin'de kadınların hane gelirinden alacakları payın çok daha düşük olması beklenmektedir. Çalışmada gelirin hane üyeleri arasında eşit bir şekilde dağılıp dağılmadığını incelemek üzere yine aynı tablodan yararlanılmıştır. Buna göre Mardin'de bireysel gelire sahip olan kadınların (34), 13 tanesinin gelirini eşine vermediği görülmektedir. Bu durum kadınların ortalama gelir düzeyinin düşüklügü ile ilgili olabilir. Mardin’de gelirinin tamamını (9) ve gerektiği kadarını (9) eşine verdiğini belirten 18 kadın bulunmaktadır. Yine Mardin'de erkeklerin yaklaşı \%44’ü gelirlerinin bir kısmını, \%35’i ise gerektiği kadarını eşlerine verdiklerini belirtmişlerdir. Alan bulgularından çıkarılan izlenimlere göre "gerektiği kadar" ifadesi kadınların bireysel ihtiyaçları için gerekli olandan ziyade, hane pazar masrafları, evin ve çocukların genel ihtiyaçları için gerekli olanı ifade etmektedir. Mardin'de gelirinden eşine bir pay vermeyen erkeklerin oranı ise yaklaşı \% 16'dır. Muğla'da ise kadınların neredeyse yarısı (\%46) gelirlerinin tamamını eşlerine verirken, erkeklerin yarısı ise bireysel gelirlerinden kadınlara sadece gerektiği kadarını vermektedir. Bu oranlar her iki ilde de hane gelirinin eşler arasında eşit bir şekilde paylaşılmadığını ve gelirin hane içindeki bölüşümünün kadınlar aleyhine gerçekleştiğini ortaya koymakta ve bu anlamda uluslararası literatürdeki bulgular ile örtüşmektedir. 
Tablo 2: Gelir Birleştirme Yaklaşımı ve Gelirin Hane İçi Bölüşümü: Mardin-Muğla

\begin{tabular}{|c|c|c|c|c|c|c|}
\hline & \multicolumn{3}{|l|}{ Mardin } & \multicolumn{3}{|l|}{ Muğla } \\
\hline & $\begin{array}{l}\text { Kadın } \\
(204)\end{array}$ & Erkek (204) & $\begin{array}{l}\text { Toplam } \\
(408)\end{array}$ & $\begin{array}{l}\text { Kadın } \\
(204)\end{array}$ & Erkek (204) & $\begin{array}{l}\text { Toplam } \\
(408)\end{array}$ \\
\hline \multicolumn{7}{|c|}{ Bireysel ve Hane Gelir Düzeyi (Aylk Ortalama TL) } \\
\hline Hane Geliri & $1.637,3$ & $1.858,4$ & $1.747,8$ & $2.913,6$ & $2.908,2$ & $2.910,9$ \\
\hline Bireysel Gelir & 147,8 & $1.339,6$ & 743,7 & 841,9 & $1.889,3$ & $1.365,6$ \\
\hline \multicolumn{7}{|c|}{ Hane Üyeleri Tarafından Kazanılan Gelirin Birleștirilip Birleștirilmediği } \\
\hline Birleștiriliyor & $56(27,5)$ & $60(29,4)$ & $116(28,4)$ & $124(60,8)$ & $117(57,4)$ & $241(59,1)$ \\
\hline Birleştirilmiyor & $148(72,5)$ & $144(70,6)$ & $292(71,6)$ & $80(39,2)$ & $87(42,6)$ & $167(40,9)$ \\
\hline \multicolumn{7}{|c|}{ Birleştirilen Gelirden Yapılan Harcamalar } \\
\hline & \begin{tabular}{|l} 
Kadın \\
$(56)$
\end{tabular} & \begin{tabular}{|l} 
Erkek \\
$(60)$
\end{tabular} & \begin{tabular}{|l} 
Toplam \\
$(116)$
\end{tabular} & \begin{tabular}{|l} 
Kadın \\
$(124)$
\end{tabular} & \begin{tabular}{|l} 
Erkek \\
$(117)$
\end{tabular} & \begin{tabular}{|l} 
Toplam \\
$\mathbf{( 2 4 1 )}$
\end{tabular} \\
\hline Kira-faturalar & \begin{tabular}{|l}
56 \\
$(100)$
\end{tabular} & \begin{tabular}{|l}
53 \\
$(88,3)$
\end{tabular} & $\begin{array}{l}109 \\
(94)\end{array}$ & $\begin{array}{l}115 \\
(92,7)\end{array}$ & $\begin{array}{l}107 \\
(91,5)\end{array}$ & $\begin{array}{l}222 \\
(92,1)\end{array}$ \\
\hline Kredi taksiti/borç & \begin{tabular}{|l}
41 \\
$(73,2)$
\end{tabular} & \begin{tabular}{|l|}
45 \\
$(75)$
\end{tabular} & \begin{tabular}{|l}
86 \\
$(74,1)$
\end{tabular} & $\begin{array}{l}100 \\
(80,6)\end{array}$ & $\begin{array}{l}95 \\
(81,2)\end{array}$ & $\begin{array}{l}195 \\
(80,9)\end{array}$ \\
\hline Tasarruf & $\begin{array}{l}28 \\
(50)\end{array}$ & $\begin{array}{l}31 \\
(51,7)\end{array}$ & $\begin{array}{l}59 \\
(50,9)\end{array}$ & \begin{tabular}{|l}
65 \\
$(52,4)$
\end{tabular} & $\begin{array}{l}65 \\
(55,6)\end{array}$ & $\begin{array}{l}130 \\
(53,9)\end{array}$ \\
\hline Gida & $\begin{array}{l}53 \\
(94,6)\end{array}$ & $\begin{array}{l}53 \\
(88,3)\end{array}$ & $\begin{array}{l}106 \\
(91,4)\end{array}$ & $\begin{array}{l}107 \\
(86,3)\end{array}$ & $\begin{array}{l}05 \\
(89,7)\end{array}$ & $\begin{array}{l}212 \\
(88)\end{array}$ \\
\hline Giyim & $\begin{array}{l}42 \\
(75)\end{array}$ & \begin{tabular}{|l|}
45 \\
$(75)$
\end{tabular} & \begin{tabular}{|l|}
87 \\
$(75)$
\end{tabular} & $\begin{array}{l}99 \\
(79,8)\end{array}$ & $\begin{array}{l}105 \\
(89,7)\end{array}$ & $\begin{array}{l}204 \\
(84,6)\end{array}$ \\
\hline Sağlık & $\begin{array}{l}49 \\
(87,5) \\
\end{array}$ & $\begin{array}{l}46 \\
(76,7)\end{array}$ & $\begin{array}{l}95 \\
(81,9)\end{array}$ & $\begin{array}{l}98 \\
(79)\end{array}$ & $\begin{array}{l}102 \\
(87,2)\end{array}$ & \begin{tabular}{|l|}
200 \\
$(83)$
\end{tabular} \\
\hline Ulaşım & $\begin{array}{l}42 \\
(75)\end{array}$ & \begin{tabular}{|l}
42 \\
$(70)$
\end{tabular} & $\begin{array}{l}84 \\
(72,4)\end{array}$ & $\begin{array}{l}103 \\
(83,1)\end{array}$ & $\begin{array}{l}97 \\
(82,9)\end{array}$ & $\begin{array}{l}200 \\
(83)\end{array}$ \\
\hline Eğlence-tatil-hobi & \begin{tabular}{|l|}
36 \\
$(64,3)$
\end{tabular} & $\begin{array}{l}37 \\
(61,7)\end{array}$ & $\begin{array}{l}73 \\
(62,9)\end{array}$ & $\begin{array}{l}89 \\
(71,8)\end{array}$ & $\begin{array}{l}92 \\
(78,6)\end{array}$ & $\begin{array}{l}181 \\
(75,1)\end{array}$ \\
\hline $\begin{array}{l}\text { Eğitim/Çocuğa yönelik } \\
\text { harcama }\end{array}$ & $\begin{array}{l}41 \\
(73,2)\end{array}$ & \begin{tabular}{|l}
42 \\
$(70)$
\end{tabular} & $\begin{array}{l}83 \\
(71,6)\end{array}$ & $\begin{array}{l}70 \\
(56,5)\end{array}$ & $\begin{array}{l}78 \\
(66,7)\end{array}$ & $\begin{array}{l}148 \\
(61,4)\end{array}$ \\
\hline Alkol-sigara & \begin{tabular}{|l}
34 \\
$(60,7)$ \\
\end{tabular} & $\begin{array}{l}25 \\
(41,7) \\
\end{array}$ & $\begin{array}{l}59 \\
(50,9)\end{array}$ & $\begin{array}{l}58 \\
(46,8)\end{array}$ & \begin{tabular}{|l|}
58 \\
$(49,6)$
\end{tabular} & \begin{tabular}{|l|}
116 \\
$(48,1)$
\end{tabular} \\
\hline \multicolumn{7}{|c|}{ Gelirinin Ne Kadarını Eşine Verdiği ${ }^{1}$} \\
\hline & Kadın (34) & Erkek (193) & \begin{tabular}{|l} 
Toplam \\
$(227)$
\end{tabular} & \begin{tabular}{|l} 
Kadın \\
$(133)$ \\
\end{tabular} & Erkek (204) & \begin{tabular}{|l} 
Toplam \\
$(\mathbf{3 3 7})$
\end{tabular} \\
\hline Tamamını & 9 & 11 & 20 & 61 & 60 & 121 \\
\hline Gerektiği kadarını & 9 & 67 & 76 & 35 & 102 & 137 \\
\hline Bir kısmını & 3 & 85 & 88 & 8 & 18 & 26 \\
\hline Vermiyor & 13 & 30 & 43 & 29 & 24 & 53 \\
\hline
\end{tabular}

Not: Parantez içerisindeki değerler yüzde değerleri göstermektedir. 


\subsubsection{Pazarlık Gücü Yaklaşımı ve Harcamaların Hane İçerisindeki Olası Dağılımı}

Uluslararası literatürün ortaya koyduğu üzere gerek gelişmiş gerek gelişmekte olan ülkeler için yapılan çalışmalarda, kadınların kontrol ettiği gelirdeki artışların harcamaların hane içerisindeki dağılımını daha çocuk merkezli hale getirdiği ve dolayısıyla çocuklar lehine yapılan harcamaları arttırarak çocukların refahını iyileştirdiği tespit edilmiştir. Ataerkil ülkelerde ise gelirin kontrolünün genellikle erkeklerin elinde toplandığı söylenebilir. Çalışmada ataerkil yapının farklı şekillerde ortaya çıktığı Mardin ve Muğla’da gelirin kontrolünün kimin elinde toplandığını incelemek amacıyla görüşmecilere kazandığı geliri nasıl kullanacağına ve hane içinde neye ne kadar para harcanacağına yönelik çeşitli kararların ağırlıklı olarak kim/kimler tarafından alındığına ilişkin soru yöneltilmiştir. Tablo 3’ten görülebileceği üzere, Mardin’de erkek görüşmecilerin yaklaşık yarısı bireysel gelirlerini nasıl kullanacağına ilişkin tek başlarına takdir yetkisine sahip olduklarını belirtirken, kazandığı geliri nasıl kullanacağına kendisinin karar verdiğini belirten sadece 15 kadın bulunmaktadır. Muğla'da ise kazandığı geliri nasıl kullanacağına kendisinin karar verdiğini belirten 29 kadın ve 52 erkek bulunmaktadır. Hane içerisinde neye ne kadar para harcanacağına kendi karar veren Mardin'de 18 kadın 77 erkek, Muğlada ise 25 kadın ve 58 erkek bulunmaktadır. Kısaca özetlemek gerekirse, her iki ilde de hane üyeleri tarafından elde edilen gelirin kontrolü ve söz konusu gelirin çeşitli harcama kalemleri arasındaki dağılımı genel itibariyle erkekler tarafından gerçekleştirilmektedir. Ancak ataerkil yapının görece daha baskın olduğu Mardin’de gelirin daha belirgin bir şekilde erkekler tarafından kontrol edildiğini söylemek mümkündür.

Tablo 3: Hane İçi Gelirin Kontrolüne Illişkin Mevcut Durum: Mardin-Muğla

\begin{tabular}{|l|l|l|l|l|}
\hline \multicolumn{2}{|l|}{} & \multicolumn{2}{|l|}{ Mardin } & \multicolumn{2}{l|}{ Muğla } \\
\cline { 2 - 5 } & $\begin{array}{l}\text { Kadın } \\
(\mathbf{2 0 4})\end{array}$ & $\begin{array}{l}\text { Erkek } \\
(\mathbf{2 0 4})\end{array}$ & $\begin{array}{l}\text { Kadın } \\
(\mathbf{2 0 4})\end{array}$ & $\begin{array}{l}\text { Erkek } \\
(\mathbf{2 0 4})\end{array}$ \\
\hline Kazandığı geliri nasıl kullanacağına kendi karar veriyor. & $\begin{array}{l}15 \\
(7,4)\end{array}$ & $\begin{array}{l}100 \\
(49)\end{array}$ & $\begin{array}{l}29 \\
(14,2)\end{array}$ & $\begin{array}{l}52 \\
(25,5)\end{array}$ \\
\hline Neye ne kadar para harcanacağına kendi karar veriyor. & $18(8,8)$ & $77(37,7)$ & $25(12,3)$ & $58(28,4)$ \\
\hline
\end{tabular}

Not 1: Söz konusu soruya "ben karar veririm" cevabı haricinde, "ortak karar veririz ama benim fikrim ağır basar", "eşim karar verir", "çocuklar karar verir", "ortak karar veririz", "aile büyükleri karar verir”, "ortak karar veririz ama eşimin fikri ağır basar" ve "hane içinde böyle bir karar alınmamaktadır” gibi cevaplar da alınmıștır. Bu nedenle hane içerisinde çeşitli konularla ilgili alınan kararların toplamı genel toplama eşit değildir.

Not 2: Parantez içerisindeki değerler yüzde değerleri göstermektedir.

Hane içinde gelirin kontrolüne ilişkin mevcut durum incelendikten sonra aşağıdaki Tablo 4 yardımıyla Mardin ve Muğla örneğinden hareketle Türkiye’de gelirin kontrolünün kadınların/ erkeklerin elinde olmasının ve kadınların/erkeklerin kontrol ettiği gelirin artmasının hane harcamaları üzerindeki olası etkileri araştırılmış böylelikle kolektif modelin pazarlık gücü yaklaşımının geçerliliği incelenmiştir. Tablonun sol tarafında görüşmecilere yöneltilen "mevcut toplam hanehalkı gelir düzeyi değişmemek şartıyla, eğer gelirin tamamı sizin elinizde olsa idi öncelikli olarak neye daha fazla harcamada bulunmak isterdiniz?" sorusuna alınan cevaplar yer 
almaktadır. Mardin'de söz konusu soruya en fazla verilen cevaplar sırasıyla gıda, eğitim, birikim/ yatırım ve sağlık iken, Muğla'da ise sırasıyla birikim/yatırım, gıda, eğitim ve eğlencedir. İki il arasında dikkati çeken farklılık Mardin'de gıda harcaması ile Muğla'da eğlence harcamasının görece yüksekliğidir. Bireylerin biri zorunlu diğeri ise lüks olan bu kalemlere daha fazla harcamada bulunmak istediklerini beyan etmeleri, iki il arasındaki gelir düzeyi farklılığı ile açıklanabilir. Cinsiyetler açısından bir karşılaştırma yapılırsa, Mardin'de gelirin kontrolünün kadınların elinde olması durumunda erkeklerin elinde olması durumuna göre gıda, giyim, çocuğa yönelik harcamalar, mobilya/ev eşyası ve evin genel ihtiyaçlarına yönelik harcamalar daha fazla yapılacaktır. Muğla’da ise gelirin kontrolünün kadınların elinde olması durumunda eğitim, giyim, çocuğa yönelik harcamalar, mobilya/ev eşyası ve evin genel ihtiyaçlarına yönelik harcamalar daha fazla yapılacaktır. Başka bir deyişle gelirin kontrolünün kadınların elinde olması hane harcamaları içerisinde gıda, giyim ve evin genel ihtiyaçları gibi zorunlu harcamalar ile eğitim ve çocuklara yönelik harcamalar gibi gelecek nesillere yönelik harcamaların payını arttıracaktır. Bu bulgu uluslararası literatürün gelirin kontrolünün kadınların elinde olmasının, harcamaların hane içi dağılımını çocuklar lehine iyileştireceği görüşünü desteklemektedir. Yine toplam hanehalkı gelir düzeyi değişmemek şartıyla, gelirin kontrolünün erkeklerin elinde olması durumunda her iki ilde de birikim/yatırım, araba/motosiklet ve gayrimenkule yönelik harcamalar artacaktır.

Tablonun sağ tarafında ise görüşmecilere yöneltilen "hane geliri iki katına çıksaydı ve gelirin kontrolü sizin elinizde olsaydı neye daha fazla harcamada bulunmak veya ne almak isterdiniz?” sorusuna verilen cevaplar yer almaktadır. Her iki ilde de bu soruya en fazla verilen cevaplar sırasıyla birikim/yatırım ve gayrimenkuldür. Ev sahibi olma isteği her iki ilde de sıklıkla dile getirilmiştir. İki il arasında dikkati çeken farklılık ise, üçüncü sırada Mardin'de mobilya/ev eşyası, Muğla'da eğlence harcamasının yer almasıdır. Hane gelirinin iki katına çıktığı varsayımı hane harcamalarını gıda, eğitim ve sağlık gibi zorunlu harcamalardan mobilya ve eğlence gibi daha lüks harcamalara doğru kaydırmıştır. Cinsiyetler açısından bir karşılaştırma yapılırsa, her iki ilde de hane gelirinin iki katına çıkması ve gelirin kontrolünün kadınların elinde olması durumunda erkeklerin elinde olması durumuna göre giyim, çocuğa yönelik harcamalar ve mobilya/ev eşyası için hane bütçesinden daha fazla pay ayrılacaktır. Bu harcamalara ilaveten artan gelirin kontrolünün kadınların elinde olması Mardin'de sağlık ve gayrimenkul, Muğla’da ise gıda, eğitim, birikim/yatırım ve evin genel ihtiyaçlarına yapılan harcamaları arttıracaktır. Başka bir deyişle gelirin kontrolünün kadınların elinde olması eğitim ve sağlık gibi beşeri sermaye yatırımlarının ve çocuklara yönelik harcamalar gibi gelecek nesillere yönelik harcamaların payını arttıracaktır. Bu bulgu yine uluslararası literatürün kadınların kontrol ettiği gelirdeki artışların, harcamaların hane içi dağılımını çocuklar lehine iyileştireceği görüşüyle örtüşmektedir. Hane gelirinin iki katına çıkması ve gelirin kontrolünün erkeklerin elinde olması ise her iki ilde de araba, motosiklet ve eğlence harcamalarını arttıracaktır. Söz konusu bulgular aynı hanede yaşayan kadın ve erkeklerin farklı tercihlere ve hane içinde farklı harcama dağılımı sonuçlarına sahip olduklarını göstermesi açısından kolektif modeli desteklemektedir. 


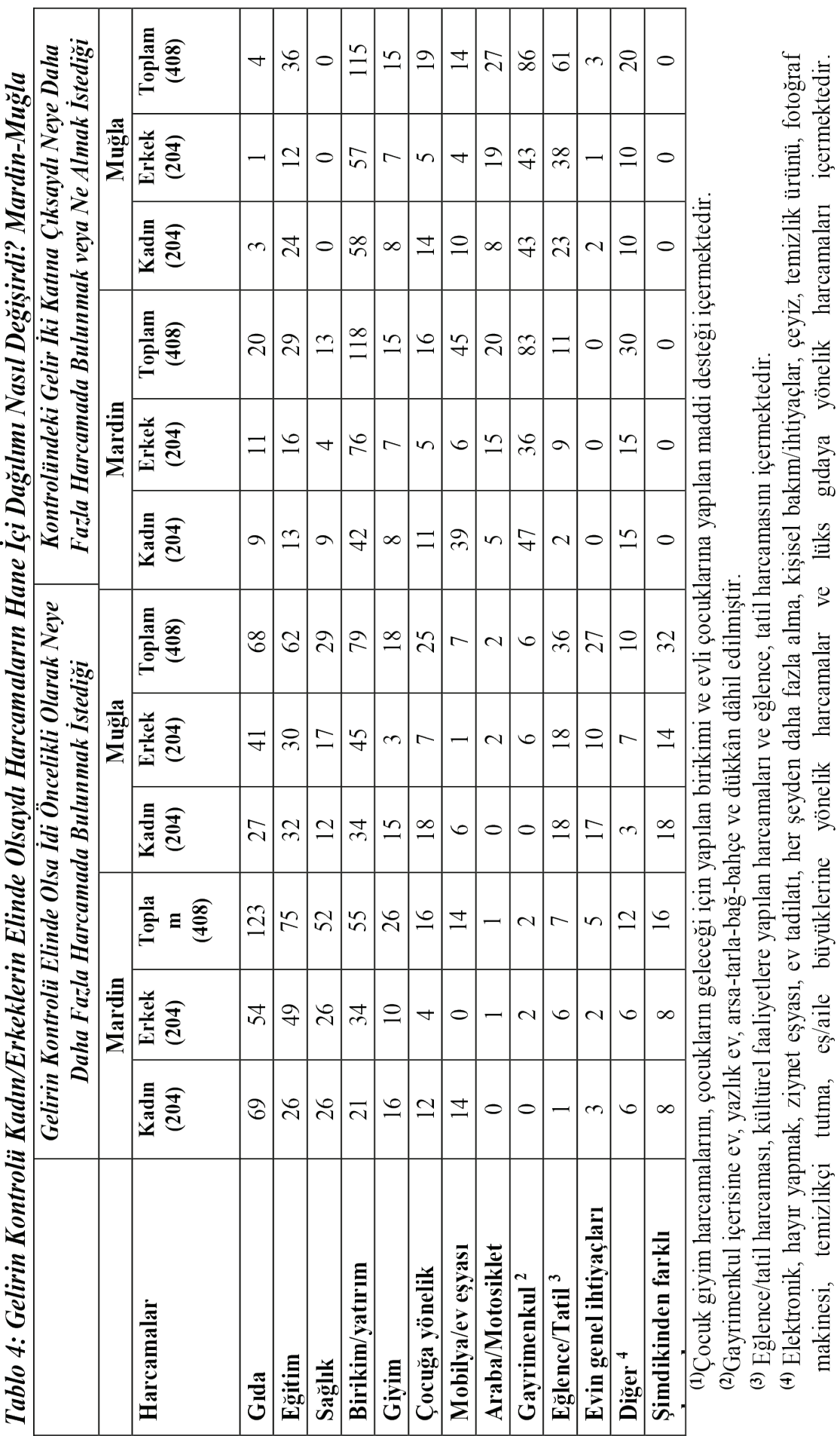




\section{Sonuç}

Bu çalışma hane davranışlarını açıklayan üniter ve kolektif modeller yardımıyla, Türkiye'de hane üyeleri tarafından elde edilen gelirin birleștirilip birleştirilmediğini araştırmayı ve gelirin kontrolünün kadınların/erkeklerin elinde olmasının harcamaların hane içi dağılımı üzerindeki olası etkilerini incelemeyi amaçlamaktadır. Bu amaçla Mardin ve Muğla Merkez ilçelerinde yaşayan farklı sosyo-ekonomik özelliklere sahip 408 evli çifte anket uygulanmıştır. Alan araştırması bulgularına göre, her iki ilde de kadınların okullaşma süreleri, işgücüne katılım oranları, ortalama çalışma süreleri ve dolayısıyla ortalama bireysel gelirleri erkeklere göre daha düşüktür. Ancak Mardin'de söz konusu alanlarda yaşanan cinsiyet eşitsizlikleri Muğla’dan daha yüksektir.

Çalışmada hane üyelerinin hane içi kararlarda her zaman hemfikir olan bir bireymiş gibi davranarak gelirlerini birleştirdiğini varsayan üniter modelin gelir birleştirme hipotezinin geçerli olup olmadığını araştırmak amacıyla gelirin birleştirilip birleştirilmediği ve aynı hanede yaşayan eşler arasında nasıl dağıldığ incelenmiştir. Buna göre Mardin’de hanelerin yaklaşık \%72'si Muğla'da ise \%41'i gelirin birleştirilmediğini beyan etmişlerdir. Söz konusu veriye istinaden hanelerin büyük bir çoğunluğunda gelirlerin birleştirilmediğini ve dolayısıyla üniter modelin gelir birleştirme yaklaşımının Muğla ve Mardin örneğinde reddedildiğini söylemek mümkündür. Her iki ilde de gelirin birleştirildiğini ifade eden görüşmecilerin büyük bir çoğunluğu gelirlerini fatura, gıda, sağlık ve giyim harcaması gibi zorunlu harcamalar için birleştirdiklerini belirtmişlerdir. Gelirin hane içi dağılımı incelendiğinde ise, her iki ilde de hane gelirinin eşler arasında eşit bir şekilde paylaşılmadığı tespit edilmiştir. Hane gelirinin dağılımında kadınlar aleyhine gözlenen eşitsizlik Mardin'de daha fazladir.

Çalışmada ayrıca haneye giren gelirinin kim tarafından kontrol edildiğinin harcamaların hane içerisindeki dağılımını etkilediğini varsayan kolektif modelin pazarlık gücü yaklaşımının geçerli olup olmadığ 1 araştırılmıştır. Bu amaçla öncelikle hane içinde gelirin kontrolünün kimin elinde toplandığı ve harcamaların hane içi dağılımına yönelik kararların ağırlıklı olarak kim tarafından alındığına ilişkin mevcut durum incelenmiştir. Buna göre, Mardin’de daha belirgin olmak üzere her iki ilde de hane üyeleri tarafından elde edilen gelirin kontrolü ve söz konusu gelirin çeşitli harcama kalemleri arasındaki dağılımının genel itibariyle erkekler tarafından gerçekleştirildiği tespit edilmiştir. Ardından gelirin kontrolünün kadınların/erkeklerin elinde olmasının ve kadınların/erkeklerin kontrol ettiği gelirin artmasının hane harcamaları üzerindeki olası etkileri incelenmiştir. Araştırma sonuçlarına göre her iki ilde de gelirin kontrolünün kadınların elinde olması durumunda erkeklerle karşılaştırıldığında mobilya, giyim, çocuğa yönelik harcamalar ve evin genel ihtiyaçlarına yönelik harcamalar daha fazla yapılacaktır. Söz konusu harcamalara ilaveten Mardin'de gıda Muğla'da ise eğitim harcaması artacaktır. Gelirin kontrolünün erkeklerin elinde olması durumunda her iki ilde de birikim/yatırım, araba/motosiklet ve gayrimenkule yönelik harcamalar artacaktır. Hane gelirinin iki katına çıkması ve gelirin kontrolünün kadınların elinde olması durumunda her iki ilde mobilya ve çocuğa yönelik harcamalar, erkeklerin elinde olması durumunda ise araba/motosiklet ve eğlence harcamaları artacaktır. Bu bulgular uluslararası 
literatürün gelirin kontrolünün kadınların elinde olmasının ve kadınların kontrol ettiği gelirin artmasının, çocuklara yönelik harcamaları arttırarak harcamaların hane içi dağılımını çocuklar lehine iyileştireceği böylece gelecek nesillere kaynak aktarımında bulunulmasını sağlayacağı görüşünü desteklemektedir. Söz konusu bulgular aynı hanede yaşayan kadın ve erkeklerin farklı tercihlere ve farklı harcama dağılımı sonuçlarına sahip olduklarını göstermesi açısından kolektif modeli desteklemektedir.

Gelirin kontrolünün kadınların elinde olmasının gelecek nesillere yapılan yatırımları arttıracak olması, kadınların kontrolündeki gelirin arttırılmasına yönelik politikaların oluşturulması konusunu daha önemli hale getirmektedir. Kadınların özellikle de Mardin’de yaşayan kadınların ataerkil yapının baskınlığı, eğitim düzeylerinin ve işgücüne katılım oranlarının düşüklüğü ile bağlantılı olarak bireysel gelirleri ve dolayısıyla pazarlık güçleri erkeklere oranla düşüktür. Kadınların gelir düzeylerini iyileştirici politikalar, kadınların hane içi pazarlık güçlerini arttırarak gelir ve harcamaların hane içerisinde kadınlar ve çocuklar lehine dağılımını sağlayabilecektir.

$\mathrm{Bu}$ anlamda; çocukların özellikle de kız çocuklarının eğitim hakkından yararlanabilmeleri için zorunlu eğitim süresinin kesintisiz on iki yıla çıkartılması önem arz etmektedir. Bilindiği üzere 2012 yılından itibaren Türkiye'de 4+4+4 olmak üzere kesintili on iki yıllık zorunlu eğitim uygulanmaktadır. Eğitim sürecinin kesintili hale getirilmesi ise özellikle kız çocuklarının eğitim sürecinden kopmasına ve örgün eğitim ortamının dışında kalmasına neden olabilecek; böylelikle toplumsal cinsiyet eşitsizliğini daha da derinleştirecektir ${ }^{65}$. Yine devletin kız çocuklarını okula gönderen ailelere vermiş olduğu maddi desteğin arttırılması kız çocuklarının okullaşma oranlarını yükseltebilir. Kadınların okullaşma oranlarının arttırılması sadece daha eğitimli kadınlar yaratmayacak aynı zamanda Türkiye’de çok düşük oranda seyreden kadınların istihdama katılımlarını ve dolayısıyla bireysel gelirlerini arttırarak hane içinde harcamaların kadınlar aleyhine dağılımını engelleyebilecektir ${ }^{66}$.

Okullaşma oranının arttırılmasına yönelik söz konusu politikalara ilaveten düşük düzeyde seyreden kadınların işgücüne katılım oranlarının da arttırılması gerekmektedir. Bu amaçla devlet kurumlarında istihdam edilen kadınların sayısı arttırılmalı, özel sektörde ise kadınları istihdam edenlere vergi ve sigorta primi kolaylı̆̆ şseklinde teşvikler verilmelidir. Yine İŞ-KUR tarafından yönetilen "toplum yararına çalışma programı" başlığı altında kadınların sayısı arttırılmalıdır ${ }^{67}$. Kadınların işgücüne katılım oranlarının arttırılması adına çalışma koşullarının iyileştirilmesi, kurumsal destek ve hizmetlerin arttırılması, çocuk ve hasta bakımının kamusal alana yayılması, çocukbakımı için ücretsiz kreşlerin ve gündüzbakımevlerinin sayısının arttırılması gerekmektedir. Yine mevcut 25522 no'lu kanunun değiştirilerek, işyerlerinin çocuk bakımevi açması için sadece kadın sayısını değil, çocuklu erkek sayısını da dikkate alacak şekilde değiștirilmesi, söz konusu

65 Özaydınlık, K. (2014). Toplumsal Cinsiyet Temelinde Türkiye’de Kadın ve Eğitim, Sosyal Politika Çalışmaları Dergisi, 14 (33): 107.

66 Ekiz Gökmen ve Gökovalı, 2016, s.182.

67 Gökovalı, U. (2013). Everyone’s Own Poverty: Gendering Poverty Alleviation Policies in Turkey, Women's Studies International Forum, 41(1): 65-75. 
tesislerin sayısının artması adına önemli bir çaba olacaktır ${ }^{68}$. Kadınların işgücüne katılımlarının arttırılması adına girişimci kadınların desteklenmesi ve kadınlara yönelik kredi imkânlarının arttırılması ve (özellikle Mardin'de) çalışan kadınlara karşı toplumun bakış açısının değiştirilmesi de önem arz etmektedir. Bunun için ise yine genel bir eğitim seferberliği ve bilinçlendirme kampanyası gerekmektedir.

Türkiye’de işgücüne katılımda yaşanan cinsiyet eşitsizliğine ilaveten işgücü piyasasında kadınlar aleyhine gerçekleşen ücret farklılıkları ve eşitsizlikleri de, kadınların bireysel gelir düzeylerinin erkeklerden daha düşük kalmasına neden olmaktadır. Türkiye'de eşit işe eşit ücret politikası kanunlarla düzenlenmiş olmasına rağmen uygulamada karşılaşılan ücrete dayalı cinsiyet ayrımcılığının ortadan kaldırılması için gerekli önlemlerin alınması gerekmektedir. Bunun haricinde işgücüne katılımdan bağımsız olarak kadınların bireysel gelir düzeylerini arttırmak amacıyla transfer ödemeleri kadınlara yönlendirilmeli, devlet tarafından kadınlara çocuk bakımı ve ev işleri gibi hane içerisinde yaratmış oldukları katma değer için ücret verilmelidir. Yine evliliğin sona ermesi halinde kadınlara ve özellikle de çocuklu kadınlara nafaka ödenmesinin kadınların talebine bağlı olarak değil, resen gerçekleştirilmesi kadınların bireysel gelirlerini ve dolayısıyla hane içi pazarlık güçlerini arttırarak harcamaların hane içi dağılımını çocuklar ve kadınlar lehine iyileştirecektir.

\section{Kaynakça}

ADAM, C., Hoddinott, J., Ligon, E. (2003). Dynamic Intrahousehold Bargaining, Matrimonial Property Law and Suicide in Canada, Household Decisions, Gender and Development: A Synthesis of Recent Research, Derleyen: Quisumbing, A. R., Washington, International Food Policy Research Institute, Johns Hopkins University Press, s. 37-40.

ADAMAN, F., Keyder, Ç. (2006). Türkiye’de Büyük Kentlerin Gecekondu ve Çöküntü Mahallelerinde Yaşanan Yoksulluk ve Sosyal Dişlanma, http://ec.europa.eu/employment_social/social_inclusion/ docs/2006/study_turkey_tr.pdf, (Erişim Tarihi: 31.10.2008).

ALDERMAN, H., Chiappori, P. A., Haddad, L., Hoddinott, J., Kanbur, R. (1995). Unitary versus Collective Models of the Household: Is It Time to Shift the Burden of Proof?, World Bank Research Observer, 10(1): 1-19.

ATTANASIO, O., Lechene, V. (2002). Tests of Income Pooling in Household Decisions, Review of Economic Dynamics, (5): 720-748.

BECKER, G. S. (1991). A Treatise on the Family, Enlarged Edition, USA, Harvard University Press.

BOURGUiGnON, F., Browning, M., Chiappori, P. A., Lechene, V. (1993). Intra Household Allocation of Consumption: A Model and Some Evidence from French Data, Annales d' Economie et de Statistique, (29): 137-156.

BROWNING, M., Chiappori, P. A. (1998). Efficient Intra-Household Allocations: A General Characterization and Empirical Tests, Econometrica, 66(6): 1241-1278.

BROWNING, M., Bourguignon, F., Chiappori, P. A., Lechene, V. (1994). Income and Outcomes: A Structural Model of Intrahousehold Allocation, The Journal of Political Economy, 102(6): 1067-1096.

68 Ecevit, Y. (2003). "Women's Labor and Social Security", Bridging the Gender Gap in Turkey: A Mile Stone Towards Faster Socio-Economic Development and Poverty Reduction, Washington DC, Poverty Reduction and Economic Management Unit: Europe and Central Asia, World Bank, s. 73-106. 
BUTIKOFER, A., Gerfin, M., Wanzenried, G. (2009). Income Pooling and the Distribution of Individual Consumption among Couples in Switzerland, Working Papers, http://staff.vwi.unibe.ch/gerfin/ downloads/poolingsharing_oct09.pdf (Erişim Tarihi: 07.02.2011).

CHIAPPORI, P. A. (1997). "Collective Models of Household Behavior: The Sharing Rule Approach", Intrahousehold Resource Allocation in Developing Countries: Models, Methods, and Policy, Derleyen: Haddad, L., Hoddinott, J., Alderman, H., Baltimore and London, Johns Hopkins University Press for the International Food Policy Research Institute, s. 39-52.

ÇABUK, N. (2003). Güney Doğu Anadolu’da Yoksulluğun Sosyal Göstergeleri, Ankara Üniversitesi Dil ve Tarih Coğrafya Fakültesi Dergisi, 43(2): 41 - 65.

DAYIOĞLU, M., Başlevent, C. (2012). Türkiye’de Gelir Dağılımının ve Yoksulluğun Toplumsal Boyutları, Türkiye’de Refah Devleti ve Kadın, Derleyen: Dedeoğlu, S., Elveren, A. Y., İstanbul, İletişim Yayınları, s.127-157.

ECEVİT, Y. (2003). Women's Labor and Social Security, Bridging the Gender Gap in Turkey: A Mile Stone Towards Faster Socio-Economic Development and Poverty Reduction, Washington DC, Poverty Reduction and Economic Management Unit: Europe and Central Asia, World Bank, s. 73-106.

EKİZ GÖKMEN, Ç., Gökovalı, U. (2016). Hane İçine Gizlenen Kadın Yoksulluğu: Muğla-Mardin Örneği, ODTÜ Gelişme Dergisi, 43(1): 157-190.

FRANKEnBERG, E., Thomas, D. (2003). "Measuring Power", Household Decisions, Gender and Development: A Synthesis of Recent Research, Derleyen: Quisumbing, A. R., Washington DC, International Food Policy Research Institute, Johns Hopkins University Press, s. 29-36.

GOLDBERG, G. S. (2010). Summary, Synthesis, and Conclusion, Part I: The Poverty of Lone Women, Their Diversity, and Income Sources, Poor Women in Rich Countries: The Feminization of Poverty over the Life Course, Derleyen: Goldberg, G. S., New York, Oxford University Press, s. 266-301.

GÖKOVALI, U. (2013). Everyone’s Own Poverty: Gendering Poverty Alleviation Policies in Turkey, Women’s Studies International Forum, 41(1): 65-75.

GÖKOVALI, U., Danışman Işık, A., Ekiz Gökmen, Ç. (2014). Kadın Yoksulluğuna Objektif ve Subjektif Bakış: Muğla ve Mardin Örneği, Yoksulluk ve Kadın, Derleyen: Topçuoğlu, A., Aksan, G., Alptekin, D., İstanbul, Ayrıntı Yayınları, s. 337-361.

HODDINOTT, J., Haddad, L. (1995). Does Female Income Share Influence Household Expenditures?, Evidence from Cote d'Ivoire, Oxford Bulletin of Economics and Statistics, 57(1): 77-96.

KAKWANI, N., Son, H. H. (2006). Women's Earning Power and Wellbeing, UNDP, International Poverty Centre, 19, http://www.ipc-undp.org/pub/IPCOnePager19.pdf, (Erişim Tarihi: 11. 10.2010).

KIMHI, A. (2004). Gender and Intrahousehold Food Allocation in Southern Ethiopia, The Center for Agricultural Economic Research Discussion Paper, No: 9.04.

KİREN Gürler, Ö., Üçdoğruk, Ş. (2007). Türkiye’de Cinsiyete Göre Gelir Farklıllığının Ayrıştırma Yöntemiyle Uygulanmas1, Journal of Yaşar University, 2(6): 571-589.

LANCASTER, G., Ray, R. (2002). Tests of Income Pooling on Household Budget Data: The Australian Evidence, Australian Economic Papers, (41): 99-114.

LUNDBERG, S. J., Pollak, R. A., Wales, T. J. (1997). Do Husbands and Wives Pool Their Resources? Evidence from the United Kingdom Child Benefit, The Journal of Human Resources, 32(3): 463-480.

MANSER, M., Brown, M. (1980). Marriage and Household Decision-Making: A Bargaining Analysis, International Economic Review, 21(1): 31-44.

McELROY, M. B., Horney, M. J. (1981). Nash-Bargained Household Decisions: Toward a Generalization of the Theory of Demand, International Economic Review, 22(2):333-349. 
ÖZAYDINLIK, K. (2014). Toplumsal Cinsiyet Temelinde Türkiye’de Kadın ve Eğitim, Sosyal Politika Çalışmaları Dergisi, 14(33): 93-112.

PHIPPS, S. A., Burton, P. S. (1998). What's Mine is Yours? The Influence of Male and Female Incomes on Patterns of Household Expenditure, Economica, 65(260):599-613.

QUISUMBING, A. R. (1994). Intergenerational Transfers in Philippine Rice Villages: Gender Differences in Traditional Inheritance Customs, Journal of Development Economics, 43(2): 167-95.

QUISUMBING, A. R., de la Brière, B. (2000). Women's Assets and Intrahousehold Allocation in Rural Bangladesh: Testing Measures of Bargaining Power, IFPRI FCND Discussion Paper, 86.

QUISUMBING, A. R. (2003). What Have We Learned from Research on Intrahousehold Allocation?, Household Decisions, Gender and Development: A Synthesis of Recent Research, Derleyen: Quisumbing, A. R., Washington, International Food Policy Research Institute, The Johns Hopkins University Press, , s. 1-16.

QUISUMBING, A. R., Maluccio, J. A. (2003). "Intrahousehold Allocation and Gender Relations: New Empirical Evidence from Four Developing Countries", Household Decisions, Gender and Development: A Synthesis of Recent Research, Derleyen: Quisumbing, A. R., Washington, International Food Policy Research Institute, The Johns Hopkins University Press, s. 23-28.

RAZZAQUE, M. A., Ahsanuzzaman, A. (2009). Intrahousehold Resource Allocation and Women's Bargaining Power: New Evidence from Bangladesh, file://C:/Users/samsung/Downloads/ SSRN-id1550559.pdf, (Erişim Tarihi: 21.03.2015).

SALLAN GÜL, S. (2005). Türkiye’de Yoksulluğun Kadınsılaşmas1, Amme İdaresi Dergisi, 38(1): 25-45.

SELIM, R., İlkkaracan, İ. (2002). Gender Inequalities in the Labor Market in Turkey: Differentials in Wages, Industrial \& Occupational Distribution of Men and Women, http://content.csbs.utah.edu/ ehrbar/ erc2002/pdf/P405.pdf, (Erişim Tarihi: 05.12.2009).

SONG, L. (2008). In Search of Gender Bias in Household Resource Allocation in Rural China", MPRA, 8348, http://mpra.ub.uni-muenchen.de/8348, (Erişim Tarihi: 28. 07.2010).

THOMAS, D. (1990). Intra-Household Resource Allocation: An Inferential Approach, The Journal of Human Resources, 25(4): 635-664.

THOMAS, D. (1992). The Distribution of Income and Expenditure within the Household, Annales d'Economie et de Statistique, (29): 109-136.

THOMAS, D., Chen, C. L. (1994). Income Shares and Shares of Income: Empirical Tests of Models of Household Resource Allocations, RAND Labor and Population Program Working Paper Series, s. 94-108, http://www.rand.org/pubs/drafts/2005/DRU705.pdf, (Erişim Tarihi: 12. 08.2011).

TOKSÖZ, G. (2012). “Neoliberal Piyasa, Özel ve Kamusal Ataerki Çıkmazında Kadın Emeği”, Türkiye’de Refah Devleti ve Kadın, Derleyen: Dedeoğlu, S., Elveren, A. Y., İstanbul, İletişim Yayınları, s.103126.

TÜİK, (2012a). http://www.tuik.gov.tr/ulusalhesapapp/ulusalhesap.zul?tur=2, (Erişim Tarihi: 30.07.2012).

TÜİK, (2012b). İstatistiklerle Kadın 2011, Women in Statistics, Türkiye İstatistik Kurumu Matbaası, Ankara.

WARDBATTS, J. (2008). Out of the Wallet and into the Purse: Using Micro Data to Test Income Pooling, Journal of Human Resources, (43): 325-351. 